\title{
Paleo-tsunami history along the northern Japan Trench: evidence from Noda Village, northern Sanriku coast, Japan
}

\author{
Taiga Inoue ${ }^{1 *}$, Kazuhisa Goto², Yuichi Nishimura ${ }^{3}$, Masashi Watanabe ${ }^{4}$, Yasutaka lijima ${ }^{1,5}$ and Daisuke Sugawara ${ }^{2,6}$
}

\begin{abstract}
Throughout history, large tsunamis have frequently affected the Sanriku area of the Pacific coast of the Tohoku region, Japan, which faces the Japan Trench. Although a few studies have examined paleo-tsunami deposits along the Sanriku coast, additional studies of paleo-earthquakes and tsunamis are needed to improve our knowledge of the timing, recurrence interval, and size of historical and pre-historic tsunamis. At Noda Village, in Iwate Prefecture on the northern Sanriku coast, we found at least four distinct gravelly sand layers based on correlation and chronological data. Sedimentary features such as grain size and thickness suggest that extreme waves from the sea formed these layers. Numerical modeling of storm waves further confirmed that even extremely large storm waves cannot account for the distribution of the gravelly sand layers, suggesting that these deposits are highly likely to have formed by tsunami waves. The numerical method of storm waves can be useful to identify sand layers as tsunami deposits if the deposits are observed far inland or at high elevations. The depositional age of the youngest tsunami deposit is consistent with the AD 869 Jogan earthquake tsunami, a possible predecessor of the AD 2011 Tohoku-oki tsunami. If this is the case, then the study site currently defines the possible northern extent of the AD 869 Jogan tsunami deposit, which is an important step in improving the tsunami source model of the AD 869 Jogan tsunami. Our results suggest that four large tsunamis struck the Noda site between 1100 and 2700 cal BP. The local tsunami sizes are comparable to the AD 2011 and AD 1896 Meiji Sanriku tsunamis, considering the landward extent of each tsunami deposit.
\end{abstract}

Keywords: Paleo-tsunami, Sanriku coast, Japan, Tsunami deposit identification, AD 869 Jogan tsunami, Storm wave, Numerical modeling

\section{Introduction}

The Tohoku-oki earthquake $(\mathrm{Mw}=9.0)$ and tsunami that struck on March 11, 2011, generated severe damage along the Pacific coast of eastern Japan. The threat of large tsunamis is of great concern to Japan and other countries (e.g., Goto et al. 2014). Studies of tsunami deposits are important in estimating the size and recurrence interval of historical and pre-historical tsunamis, and in assessing the risk of large low-frequency tsunamis (e.g., Goto et al. 2014). Many studies have described tsunami deposits around the world (e.g., Dawson and Shi 2000; Pinegina and Bourgeois 2001; Peterson et al. 2011).

\footnotetext{
*Correspondence: taiga.inoue.r7@dc.tohoku.ac.jp

'Department of Earth Sciences, Graduate School of Science, Tohoku

University, Sendai 980-8578, Japan

Full list of author information is available at the end of the article
}

Studies of paleo-tsunami deposits along the Pacific coast of the Tohoku region (Fig. 1), which faces the Japan Trench, are the result of global collaboration. The Sendai and Ishinomaki plains, located in the southern part of the Sanriku coast, are representative locations examined in those studies and have yielded evidence for historical and pre-historical tsunamis (Minoura and Nakaya 1991; Minoura et al. 2001; Sugawara et al. 2001, 2012, 2013; Sawai et al. 2007, 2008, 2012, 2015; Shishikura et al. 2007; Satake et al. 2008; Namegaya et al. 2010; Matsumoto et al. 2012). Shishikura et al. (2007), for example, identified five possible tsunami deposits that formed during the past 3000 years and estimated a tsunami recurrence interval of $500-1000$ years. Sawai et al. (2015) proposed that the tsunami recurrence period in this region is $\sim 600$ years. The Sendai and Ishinomaki plains also contain deposits of the AD 869 Jogan tsunami (e.g., Abe et al. 1990; Minoura 


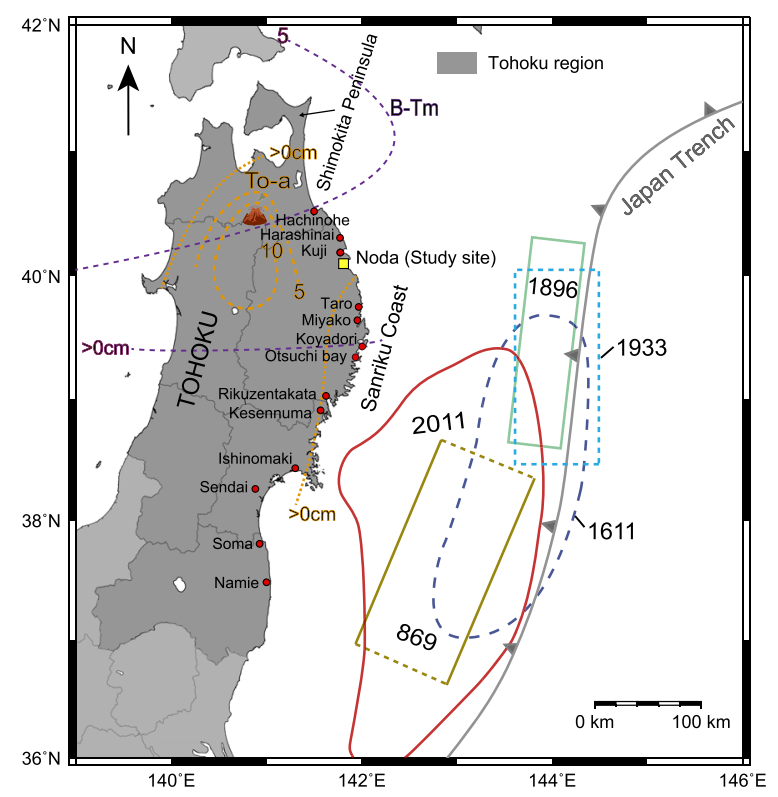

Fig. 1 Location of the study area. Dark gray area denotes the Tohoku region. Tsunami source models of the 869 Jogan (Sawai et al. 2012), 1611 Keicho (Hatori 2009), 1896 Meiji Sanriku (Tanioka and Satake 1996: Tanioka and Seno 2001), 1933 Sanriku (Kanamori 1971), and 2011 Tohoku-oki earthquakes (Ozawa et al. 2011) are shown by colored lines off the Sanriku coast. The broken lines indicate that the extent of the rupture model remains unknown. Thickness distributions $(\mathrm{cm})$ of the Towada-a (To-a) tephra of AD 915 (Machida and Arai 2003) and the Baegdusan-Tomakomai (B-Tm) tephra of AD 946 (Machida and Arai 1992) are shown by broken orange and purple lines, respectively

and Nakaya 1991; Sawai et al. 2012), which was a possible predecessor of the 2011 Tohoku-oki tsunami (e.g., Goto et al. 2011; Namegaya and Satake 2014).

In contrast to the well-studied Sendai and Ishinomaki regions, few geological studies have described tsunami deposits along the Sanriku coast. Consequently, it is necessary to elucidate the long-term tsunami history along the Sanriku coast from geological evidence. However, this region has the disadvantage of low sedimentary potential and a lack of lowlands necessary to form tsunami deposits, due to the development of a ria coast. It has also been intensely modified by agricultural development. Observation records and other historical documents indicate that large tsunamis have frequently occurred in this region (e.g., Utsu 2004; Fig. 1). In fact, within the past 400 years, the AD 1611, 1896, 1933, and 2011 tsunamis have severely affected the Sanriku coast, with maximum recorded inundation heights of 25.0, 38.2, 29.2, and $33.0 \mathrm{~m}$, respectively (Japan Tsunami Trace database: http://tsunami-db.irides.tohoku.ac.jp).

Along the Sanriku coast, Goto et al. (2015) studied the north area of Taro (Fig. 1) and identified possible tsunami deposits from the last 600 years. Ishimura and Miyauchi (2015) and Ishimura (2017) reported 11 tsunami deposits, including a possible AD 869 Jogan tsunami deposit, from the past 4000 years at Koyadori (Fig. 1). Ishimura (2017) estimated that the average recurrence interval of these deposits is 350-390 years. Farther north, on the Shimokita Peninsula (Fig. 1), Tanigawa et al. (2014) reconstructed the geological record of the past $\sim 6000$ years. Minoura et al. $(1994,2013)$ and Tanigawa et al. (2014) reported evidence of tsunami deposits that were possibly formed by the AD 1611 Keicho tsunami. Between Miyako and the Shimokita Peninsula, only two studies, Hirakawa (2012) and Takada et al. (2016), have described possible tsunami deposits. It is necessary to collect more geological evidence along the northern Sanriku coast to elucidate the size and recurrence interval of paleo-tsunamis that are generated along the Japan Trench.

It is difficult to distinguish tsunami deposits from storm and flood deposits (e.g., Morton et al. 2007; Goff et al. 2012). Therefore, a multi-proxy approach is recommended (Goff et al. 2012). Although diatom analysis might be useful to infer the origins of deposits (HenphillHaley 1996), it cannot distinguish tsunami deposits from storm deposits. Numerical methods can be used to distinguish deposits formed by tsunami and other extreme wave events. For instance, the inundation distance of storm waves is known to be generally shorter than that of tsunami waves because of the difference in wavelength (e.g., Morton et al. 2007; Watanabe et al. 2017). Therefore, in a lowland sedimentary environment, the distance that event deposits can be transported will differ for storms and tsunamis. If the event layers were deposited far beyond the numerically estimated maximum limit of inundation by storm waves, then it can be inferred that the deposits were formed by tsunami waves.

In this study, we conducted two field surveys at Noda Village, Iwate Prefecture, on the northern Sanriku coast (Fig. 1). We coupled a sedimentological approach, to accurately identify the origin of event layers at the study site, with applied numerical modeling of storm waves rather than tsunami modeling, which allowed us to test whether the distribution of event deposits can be explained by large storm waves.

\section{Study area}

Noda Village is located on the northern Sanriku coast (Fig. 1), where the geology is dominated by the Upper Cretaceous Kuji Group (Terui and Nagahama 1995). The alluvial lowland developed along rivers and marine terraces, corresponding to marine isotope stage (MIS) 1:14 ka across the Sanriku coast area (Koike and Machida 2001). In coastal areas, cliffs and shore reefs extend seaward. The beach consists of sand and gravel, which is a rare sedimentary environment on the 
northern Sanriku coast, where a ria coast is developed. Paddy fields and urban areas are distributed in the lowland area.

The study site, in the Maita area, is a narrow valley among forested hills (Fig. 2a). Present-day beach sediments consist of well-rounded gravel and sand (Fig. 2b). Wave breakers are set about $50 \mathrm{~m}$ from the shoreline. The Sanriku railway runs north-south at $\sim 300 \mathrm{~m}$ inland from the shoreline. These artificial objects were built well before the 2011 Tohoku-oki tsunami. The Maita River is $\sim 5 \mathrm{~m}$ wide, and the banks are covered by revetments. The study site is used as a rice paddy field and contains agricultural terraces (Fig. 3).

The historical tsunamis that have struck the Sanriku coast are summarized by Ishimura and Miyauchi (2015). Among historical tsunamis, it is known that the $\mathrm{AD}$ 1611, 1896, 1933, and 2011 tsunamis were particularly large. In our study area specifically, the 1896 Meiji Sanriku tsunami reached up to $\sim 880 \mathrm{~m}$ inland and $16 \mathrm{~m}$ in elevation, according to local people. No written records of large tsunamis are available before the 1896 event. The 2011 Tohoku Earthquake Tsunami Joint Survey (TTJS) Group reported that tsunami height was $22.84 \mathrm{~m}$ near the shoreline at this site and reached up to $\sim 720 \mathrm{~m}$ inland and $12 \mathrm{~m}$ in elevation (http://www.coastal.jp/ttjt/) (Fig. 3b). The inundation distances and runup heights of the 1896 and 2011 tsunamis cannot be compared directly because the wave breakers were not constructed until after the 1896 tsunami.
The gently sloping topography and low-energy wave environment of the study area promotes the preservation of tsunami deposits. In July 2011, we confirmed that the 2011 tsunami deposits were formed in the area, as shown in Fig. 2c. The 2011 tsunami deposit consists of gravel to very fine sand layers of $5-10 \mathrm{~cm}$ thickness. The deposits show normal grading and lamination and contain shell fragments. The 2011 tsunami deposit was removed during the recovery process, several months after this field survey.

\section{Methods/experimental \\ Field survey}

In November 2014 and March 2015, we conducted geological surveys and examined sediments in the coastal lowland of the study area. We set a survey transect perpendicular to the shoreline, $400-700 \mathrm{~m}$ from the sea. To retrieve cores, we used a Handy Geoslicer sampling tool of 0.6 and $1 \mathrm{~m}$ long (Takada et al. 2002) and a peat sampler. Coring sites were selected to evaluate the continuity of event deposits (NM1 to NM20 and NM-A to NM-L; Fig. 3a). Samples for analyses were taken from the cores using rectangular plastic cases $(5 \times 20 \mathrm{~cm})$. In the field and laboratory, we conducted lithological observations, made sketches, and took photographs of the cores. As for some coring sites, also used a peat sampler that can obtain samples from greater depths than the ones by Handy Geoslicer, we made a composite columnar section from both cores.

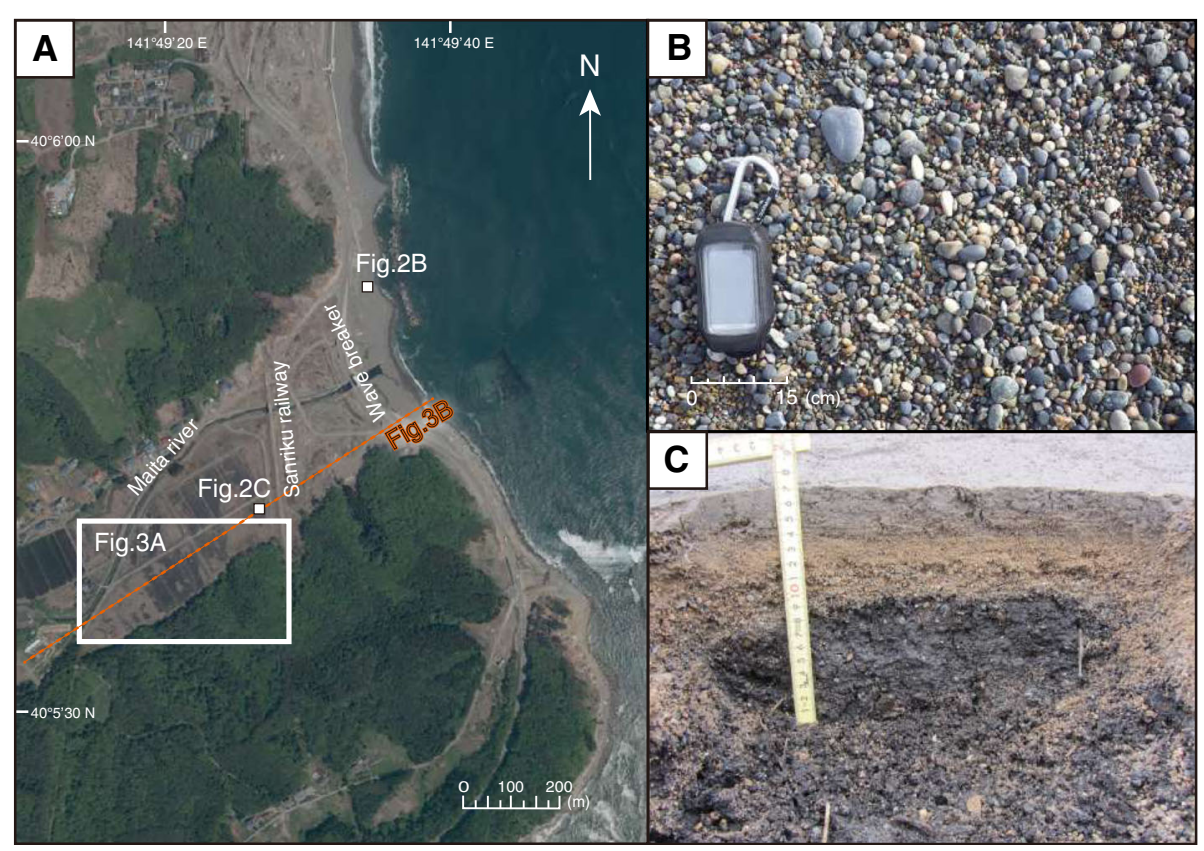

Fig. 2 a Aerial photograph of the survey area at Noda Village (CTO20112-C23-22, provided by the Geospatial Information Authority of Japan). b Sediments deposited on the nearby beach. c Typical 2011 Tohoku-oki tsunami deposits (photograph taken July 29, 2011) 


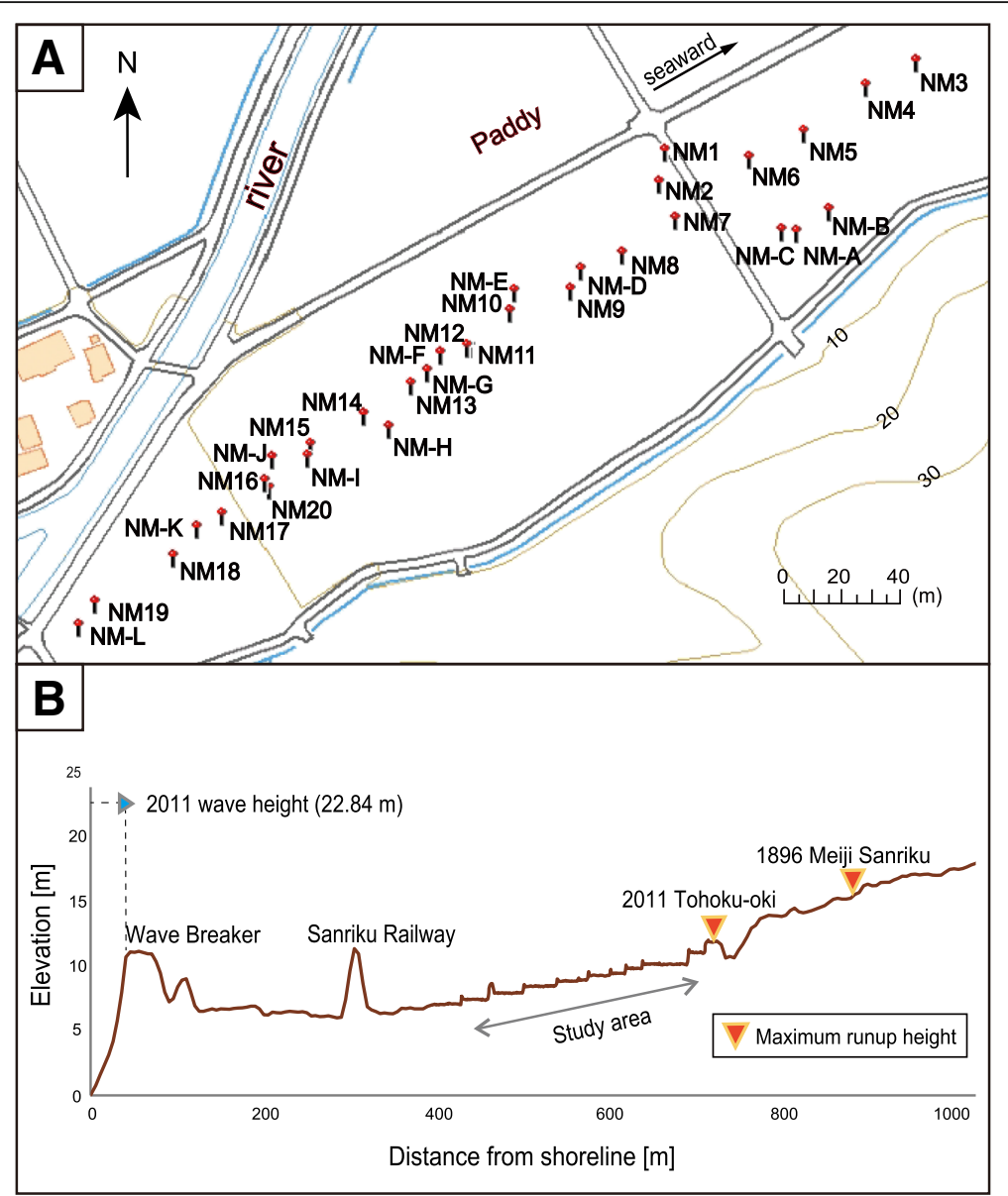

Fig. 3 a Locations of survey points NM1 to NM20 and NM-A to NM-L. b Cross-sectional topography along the transect shown in Fig. 2a. Maximum run-up heights of the 2011 Tohoku-oki and 1896 Meiji Sanriku tsunamis are shown. Tsunami height at the coast of the 2011 Tohoku-oki tsunami is based on the 2011 Tohoku Earthquake Tsunami Joint Survey (TTJS) Group

\section{Laboratory analyses}

We analyzed the grain size of the gravelly sand deposits using a CAMSIZER (Verder Scientific) at Tsukuba University, Japan. This instrument provides particle size data from $30 \mu \mathrm{m}$ to $30 \mathrm{~mm}$ (Yamada and Fujino 2013). Samples for the analysis were collected from the gravelly sand layers at $1 \mathrm{~cm}$ intervals vertically, although some samples were collected as bulk samples because they were thin $(0.5-1.5 \mathrm{~cm}$ in thickness).

We first dried samples and added $10 \%$ hydrogen peroxide to remove organic material. Then, ultrasonic cleaning was performed after drying. We removed the mud component using a $63-\mu \mathrm{m}$ sieve, as the target sediment is composed mostly of coarse sand to gravel. We chose to investigate the sand and gravel grain sizes only. After removing the mud component, we dried the samples and measured the weight. The grain size analysis results show the volume frequency of the grain size distribution.
We used radiocarbon dating to correlate event deposits among cores and to estimate the depositional ages of event layers. We performed age-dating on 20 bulk peat sediments obtained below and above the gravelly sand layers. Radiocarbon dating was conducted using accelerator mass spectroscopy (AMS) at Beta Analytic Inc. in Miami, USA. Radiocarbon ages were calibrated to calendar years using the approach of Vogel et al. (1993) and the calibration curve IntCal13 (Reimer et al. 2013).

We recognized and analyzed tephra layers in some cores, which are useful in determining the absolute age. The tephra layers were sampled from cores at 600 $650 \mathrm{~m}$ from the shoreline. To ascertain the origin of tephra quantitatively, the major element compositions were determined by energy dispersive X-ray spectrometer (EDS, JSM-5310; JEOL) at Hokkaido University, Japan, following the method of Nakamura (2016). We used $\mathrm{TiO}_{2}$ and $\mathrm{K}_{2} \mathrm{O}$ contents to identify the tephra, employing the database of Quaternary marker tephra 
provided by Aoki and Machida (2006) and data of Nakamura (2016).

\section{Numerical method to identify tsunami deposits}

We performed a numerical simulation of wave propagation and run-up using a combination of Delft-3D (Deltares 2011) and SWAN (Booij et al. 1999) software. The numerical method followed Bricker et al. (2014) and Watanabe et al. (2017). When using Delft-3D and SWAN, the hydrodynamic model repeatedly passes the water level and current fields to the wave model, which then calculates the wave field considering currents and storm surges (Bricker et al. 2014). Then, the wave model passes the radiation stress field back to the hydrodynamic model, which calculates the breaking-wave-induced setup and nearshore currents (Bricker et al. 2014).

To ensure coverage of the survey area, the numerical domain was $3-\mathrm{km}$ long and $6-\mathrm{km}$ wide. Topographic data on a 5-m grid, provided by the Geospatial Information Authority of Japan, was used for the land area, and bathymetric data on a 4-m grid, from the Central Public Disaster Prevention Council of Japan, was used for the marine area. We removed artificial embankments such as wave breakers, the Sanriku Railway, and the artificial topography created by reclamation and banking from the whole numerical domain as they are contemporary features. The computational grid size was $10 \mathrm{~m}$. Time steps of $0.01 \mathrm{~s}$ were used to ensure computational stability. The propagation and inundation extent of storm waves were simulated over a period of $4 \mathrm{~h}$.

According to the measurement records of NOWPHAS (1970-2013) (Kawaguchi et al. 2015), the previous maximum significant wave observed at Kuji, located just north of the study area (Fig. 1), had a 9.53-m wave height, with a $12.1 \mathrm{~s}$ period (recorded in 2010). Our study site is located in the northern part of Japan, where the impacts of typhoons are generally lower than in the southern subtropical region (Kawaguchi et al. 2015). Other regions in southern Japan have been affected by much larger waves: the maximum recorded significant wave heights and periods are $13.5 \mathrm{~m}$ and $15.8 \mathrm{~s}$ at Murotsu ( $\left.33^{\circ} 16^{\prime} 18^{\prime \prime} \mathrm{N}, 134^{\circ} 08^{\prime} 50^{\prime \prime} \mathrm{E}\right)$ in $2004,12.49 \mathrm{~m}$ and $16.4 \mathrm{~s}$ at Kochi $\left(33^{\circ} 2857^{\prime \prime} \mathrm{N}, 133^{\circ} 35^{\prime} 13^{\prime \prime} \mathrm{E}\right)$ in 2004 , $14.44 \mathrm{~m}$ and $16.1 \mathrm{~s}$ at Omaezaki-oki $\left(34^{\circ} 24^{\prime} 12^{\prime}{ }^{\prime} \mathrm{N}, 138^{\circ}\right.$ $16^{\prime} 30^{\prime \prime} \mathrm{E}$ ) in 2009 , and $15.14 \mathrm{~m}$ and $14.4 \mathrm{~s}$ at Owase-oki $\left(33^{\circ} 54^{\prime} 08^{\prime \prime} \mathrm{N}, 136^{\circ} 15^{\prime} 34^{\prime \prime} \mathrm{E}\right)$ in 2004 , respectively.

The highest sea-level rise caused by low atmospheric pressure during a typhoon since 1950 was recorded by the Japan Meteorological Agency at $3.89 \mathrm{~m}$ at Nagoya port $\left(35^{\circ} 05^{\prime} 00^{\prime \prime} \mathrm{N}, 136^{\circ} 53^{\prime} 00^{\prime \prime} \mathrm{E}\right)$ in 1959 . Using the storm records along the entire coast of Japan, we set a parameter, assuming a large size and an extremely large size of storm waves, and the sea-level rise for boundary conditions (Table 1). We also adopted several
Table 1 Boundary conditions for the numerical simulation

\begin{tabular}{llll}
\hline Case & Sea level $(\mathrm{m})$ & Wave height $(\mathrm{m})$ & Period $(\mathrm{s})$ \\
\hline 1A & 0 & 10 & 10 \\
1B & 0 & 15 & 15 \\
1C & 0 & 20 & 20 \\
$2 \mathrm{~A}$ & 5 & 10 & 10 \\
$2 \mathrm{~B}$ & 5 & 15 & 15 \\
$2 \mathrm{C}$ & 5 & 20 & 20 \\
\hline
\end{tabular}

Sea level, significant wave height, and period are set as the main conditions on the boundary of the numerical domain

unrealistically large assumptions for the storm wave conditions and sea-level rise at the study site (e.g., cases $1 \mathrm{C}$ and $2 \mathrm{C}$ in Table 1) to evaluate whether the lateral extent of the event layers can be explained by such exaggerated circumstances.

\section{Results}

Lithology

The stratigraphy in the study region consists mainly of black peat and black peaty silt deposited in a marsh environment (Fig. 4). The 2011 tsunami deposits were already removed at that time of this study, and the surface sediment was artificially disturbed. At each coring site, one or several gravel sand layers were interbedded within peat and peaty silt. At $20-30 \mathrm{~cm}$ below the surface, single-layer or patchy tephra were found. The gravelly sand consists of well-rounded gravel and coarse to medium sand (Fig. 5a, b) that locally shows normal grading. At site NM-K, we identified four gravelly sand layers that are named layers I to IV in descending order (Fig. 6).

Differences were found in the lithostratigraphy between the seaward and landward sides of the transect. Here, we describe the details of the lithology of NM2 (seaward side: $467 \mathrm{~m}$ inland; Fig. 5a) and NM-K (landward side: $655 \mathrm{~m}$ inland; Fig. 6) as representative cores. The characteristics of all the gravelly sand layers, such as thickness, mean grain size, and sedimentary structures, are presented in Additional file 1, Table A1.

NM2 (Fig. 5a): In this 50-cm-long core, agriculturally disturbed sediment and black peat lie at respective depths of $0-22$ and $22-50 \mathrm{~cm}$ from the surface. At depths of 28-30 and 38-46 cm, layers of gravelly sand are interbedded with the peat. Normal grading was observed in the lower layer of the gravelly sand.

NM-K (Fig. 6): In this 58-cm-long core, agriculturally disturbed sediment and black peat occur at respective depths of $0-6$ and $6-58 \mathrm{~cm}$ from the surface. At depths of $17-18,33-34,43-45$, and $53-55 \mathrm{~cm}$, gravelly sand layers are interbedded with peat or peaty silt. A thin (< $1 \mathrm{~cm}$ ) tephra layer lies $1 \mathrm{~cm}$ above the uppermost gravelly sand layer. The peat layer at $22-29 \mathrm{~cm}$ depth is 


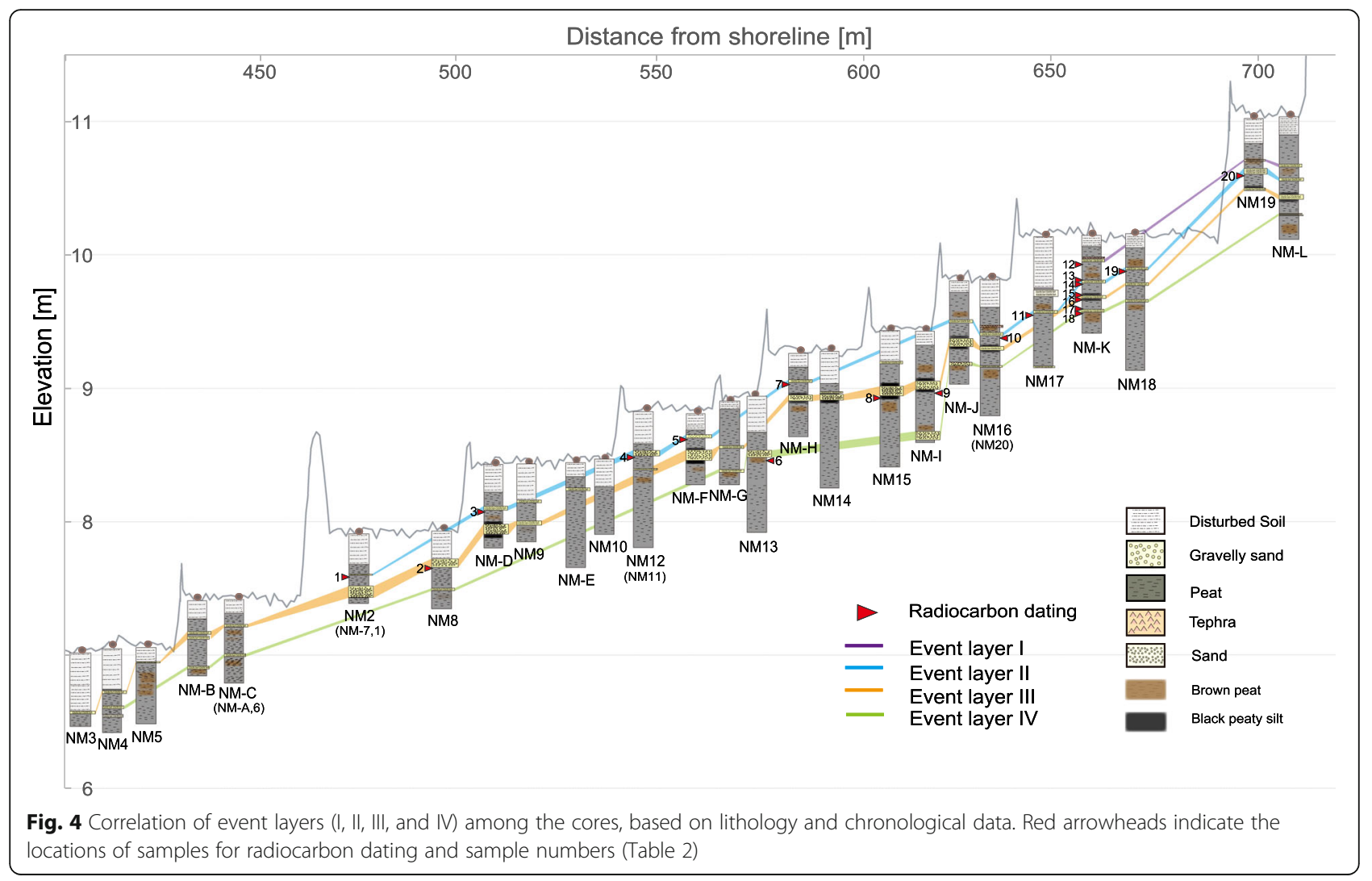

brown in color, and that at $34-47 \mathrm{~cm}$ depth is black, and the peat gradually becomes peaty silt with increasing depth below the gravelly sand layer. At $47-53 \mathrm{~cm}$ depth, the peat is mainly black in color, except for the lowest part, which is brown. The peat at $55-58 \mathrm{~cm}$ depth is brown. We used these characteristics to identify key beds for stratigraphic correlation.

The number and thickness of gravelly sand layers vary among the cores. At some sites, no gravelly sand layers were found (see Additional file 1, Table A1). The stratigraphic correlation of the gravelly sand layers between cores was based on the following criteria: (1) layer I is deposited immediately below patchy tephra or a layer of tephra, (2) brown peat occurs between layers II and III, (3) layer III is thicker than the other layer I, II, and IV, and interbedded within black peaty silt with sharp boundaries, and (4) layer IV is finer in grain size than layer III and brown peat occurs below layer IV.

Radiocarbon ages, as described below, are used to improve the accuracy of the correlation, as described in the "Discussion" section.

\section{Grain size and thickness of gravelly sand layers}

A typical example of the vertical variation in grain size is shown for the NM2 core (Fig. 5). The gravelly sands are generally poorly sorted (Fig. 5), and some show a bimodal grain-size distribution. The coarsest grain size is
- $3.41 \phi$ (in core NM-B). The lower event layer in core NM2 shows macroscopically normal grading. However, grain size analysis further revealed that variations in the mode of the diameter in the lower event layer represent repeated normal and inverse grading. In other event layers, the vertical variation in the mode of the diameter indicates various trends such as normal and inverse grading, and massive structure (Fig. 7). The NM-L core is the landward limit at which we identified gravelly sands along the transect. The maximum grain size at this site was $-2.83 \phi$.

\section{Radiocarbon dating}

Radiocarbon ages were used to confirm the continuity of sand layers and to constrain depositional ages. The ages range from 1200 to 2700 cal BP (Table 2; Fig. 4). Detailed age measurements were undertaken for the gravelly sand layers in NM-K, yielding ages of (in descending order): 1290, 2150-1930, 2310-2070, and 27502385 cal BP (Fig. 6).

\section{Tephra analysis}

Radiocarbon dating results from the NM-K core show that the tephra layer was deposited after $1290 \mathrm{cal}$ BP. Around the study site, the AD 915 Towada-a (To-a) and AD 946 Baedusan-Tomakomai (B-Tm) tephra are candidates during this period (Machida and Arai 2003; Aoki 


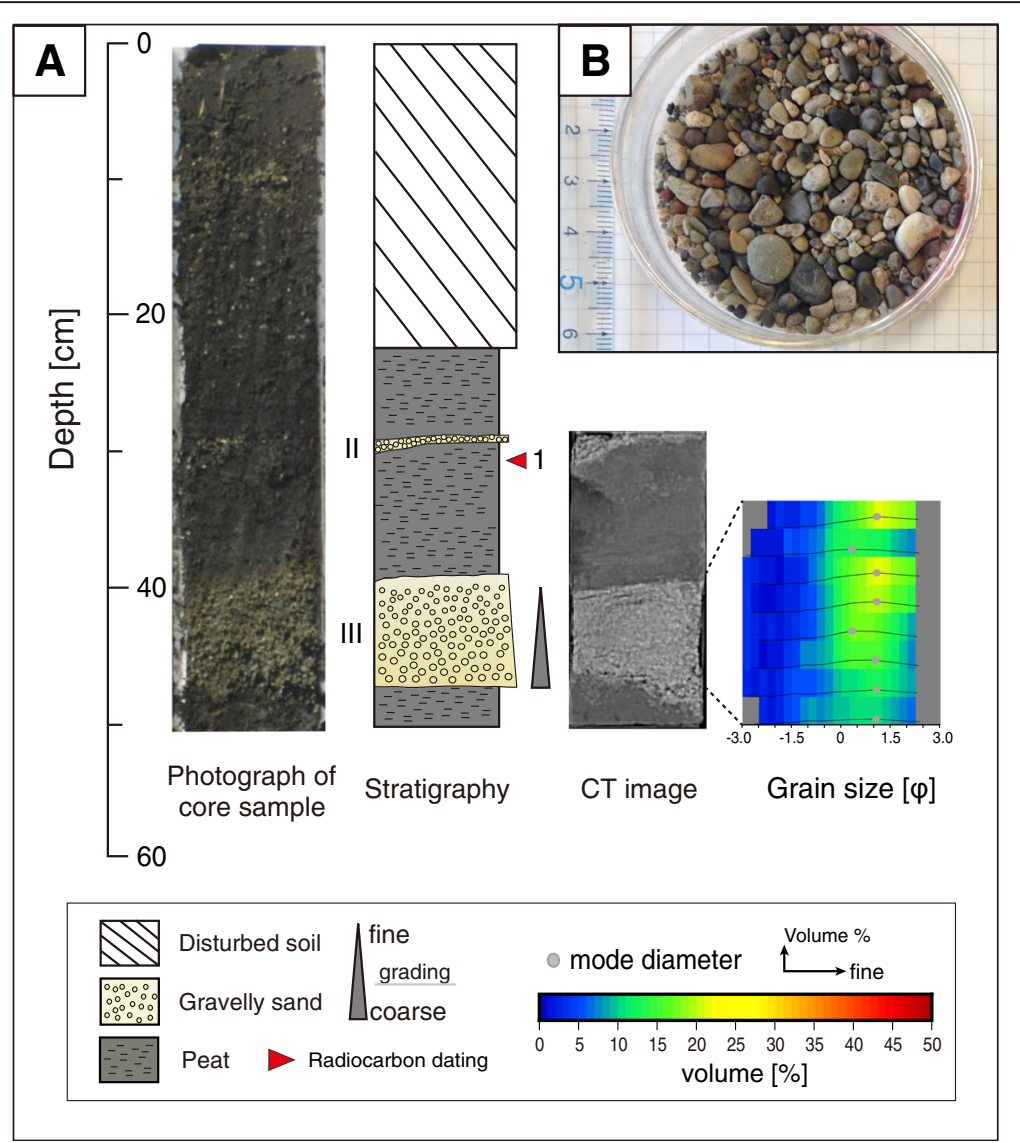

Fig. 5 a Photographs, stratigraphy, CT images, and grain size of core NM2. For the grain size diagram, the horizontal axis is grain size ( $\Phi)$ and the vertical axis is volume frequency (\%). The gray scale indicates the mode of grain diameter. The volume frequency (\%) of each grain size is indicated by the color scale. $\mathbf{b}$ Photograph of particles of layer III in core NM2 (depth 38-46 cm). Red arrowheads indicate the location of a sample for radiocarbon dating and the sample number (Table 2)

and Machida 2006; Nakamura 2016). The major element composition $\left(\mathrm{TiO}_{2}-\mathrm{KiO}_{2}\right)$ of the tephra layers at the study site is similar to that of reference samples from the To-a and B-Tm tephras investigated at Tagajo $\left(38^{\circ}\right.$ $\left.18^{\prime} 24^{\prime \prime} \mathrm{N}, 140^{\circ} 59^{\prime} 18^{\prime \prime} \mathrm{E}\right)$ and Tomakomai $\left(42^{\circ} 37^{\prime} 53^{\prime \prime} \mathrm{N}\right.$, $141^{\circ} 36^{\prime} 34^{\prime \prime} \mathrm{E}$ ) (Aoki and Machida 2006), respectively (Fig. 8). Therefore, we suggest that the tephras at the study site are the To-a and B-Tm tephras.

Although a single-tephra layer was observed, and two different kinds of tephra glass were identified in the layer, probably because the tephra layers were formed during a very short time interval. Moreover, the tephra is locally intermixed, showing patch-like features, suggesting that minor reworking occurred after sedimentation.

\section{Numerical simulation of storm waves}

Cases $1 \mathrm{C}$ and 2C in Fig. 9 are assumed to the most extremely large storm waves and sea-level rise due to low atmospheric pressure among the study cases of the simulated waves. The results show that the maximum significant wave height $(5.46 \mathrm{~m})$ and flow speed $(1.79 \mathrm{~m} / \mathrm{s})$ near the shoreline were both recorded in case $2 \mathrm{C}$. The inundation limit of storm waves is up to $450 \mathrm{~m}$ from the shoreline (7.33 $\mathrm{m}$ in elevation) if we assume an extreme case (i.e., case 2C; Fig. 9d). The inundation limit covers a small portion of the seaward section of the transect, in which the seaward end was set $410 \mathrm{~m}$ inland of the coastline and $7 \mathrm{~m}$ in elevation. The modeled inundation by storm waves is much shorter and lower than the distance and elevation of the landward end of the site with gravelly sand layers $(705 \mathrm{~m}$ inland and $11 \mathrm{~m}$ in elevation). It is important to note that this inundation can be explained mainly by the assumed sea-level rise $(5 \mathrm{~m})$ rather than the storm wave.

\section{Discussion}

\section{Correlation of event deposits}

The gravelly sand layers have clear upper and lower boundaries. Some layers show macroscopic normal grading. These features suggested that the gravelly sands were allochthonous and deposited by high-energy 


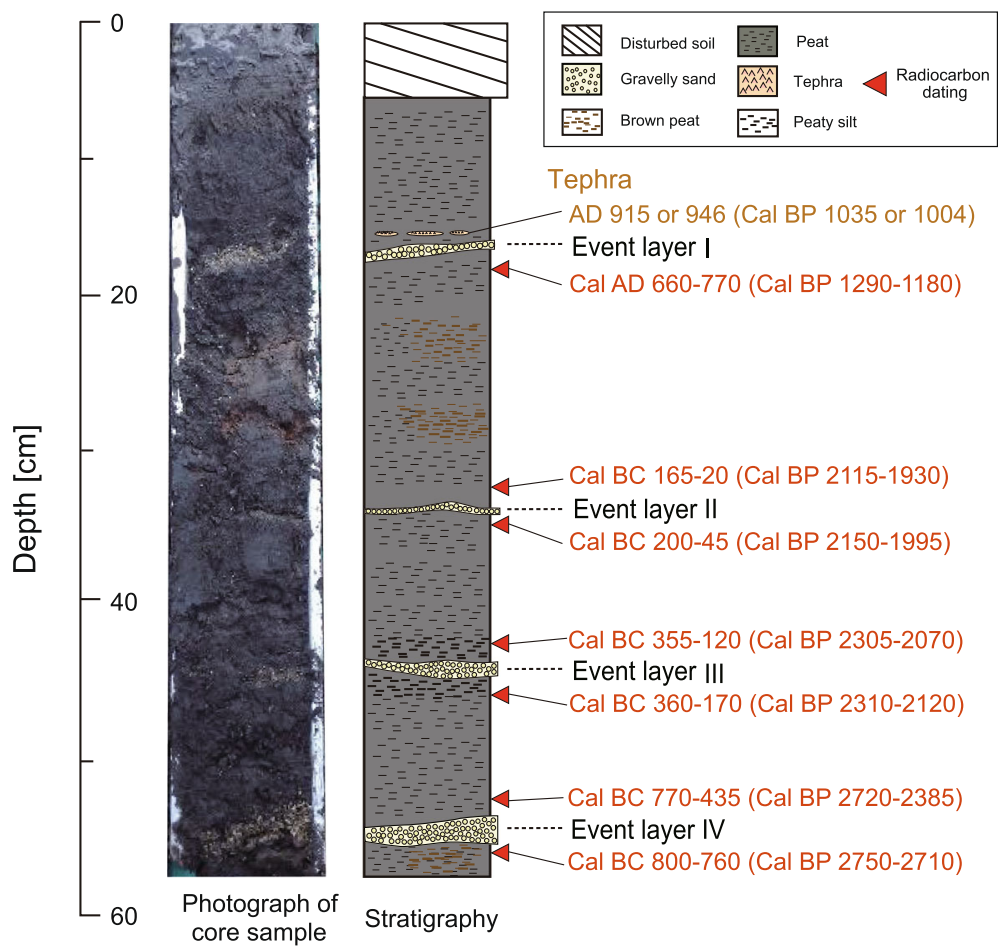

Fig. 6 Photograph, stratigraphy, and the radiocarbon dating results of core NM-K. From top to bottom, the deposits in cores NM-K are labeled as event layers I, II, III, and IV. Red arrowheads indicate the locations of samples for radiocarbon dating

events. Hereinafter, we designate these gravelly sand layers as event layers (Figs. 4 and 6).

Each event layer was correlated between cores based on lithology and radiocarbon ages (see Table A1 for a description of the event layers and criteria for stratigraphic correlation). In the seaward half of the transect (from NM-3 to NM-9), the upper and lower boundaries of the event layers are clear. The event layers along NM3 to NM-C display a remarkable difference in grain size (Table A1), which made it possible to correlate each event layer based on observations. In contrast, correlation of event layers in the middle part of the transect (from NM-E to NM12) was not easy because some layers were unclear or not visible in some cores. In the landward half of the transect (from NM-F to NM-L), the thickness of the event layers decreased landward. Consequently, correlation using only sedimentological features was not straightforward. However, radiocarbon dating results, tephra layers, brown peats, and the black peaty silt were useful as key beds to correlate event layers. Figure 4 shows the correlation of the event layers between different cores.

Based on the correlation, we clarified that event layer III is the most distinct layer in terms of lateral continuity and thickness (Fig. 4). Conversely, event layer I was only observed in the landward area, $650 \mathrm{~m}$ inland. Event layers II and IV were deposited widely but lacked continuity.

\section{Sources and identification of tsunami deposits}

Given that event layer III is the most distinct and continuous event layer, we discuss this layer first. In each coring site, some gravelly sand layers show overall normal grading (Figs. 5a and 7), indicating that event layer III was deposited under the influence of flow. Moreover, a coarser fraction (particles larger than $-3 \phi$ ) was not observed in the landward part of the transect $(>588 \mathrm{~m}$ from the shoreline), as shown by the maximum grain sizes and their thicknesses of the layers. Grain size becomes finer inland, and layers become thinner (Fig. 7), which indicates the transportation of material from the sea-side such as beach and/or ocean (Dawson 1994).

Sediment supply from river flooding or the surrounding cliffs can be ruled out for the following reasons. Firstly, the event layer particles are well rounded (Fig. 5b) and similar to particles on the beach (Fig. 2b), which supports the possibility of sediment transportation from the sea. In contrast, sediments from terrestrial cliffs are usually composed of brecciated particles (e.g., Nishina et al. 2013). Thus, the sediments of nearby cliffs are unlikely to have been the source of the event layers. Secondly, although flooding from the Maita River might have occurred in the past, such flooding was probably insufficient to explain the distribution of event layers because of the small size of the river and the small volume of material carried by the river. Deposition from river 


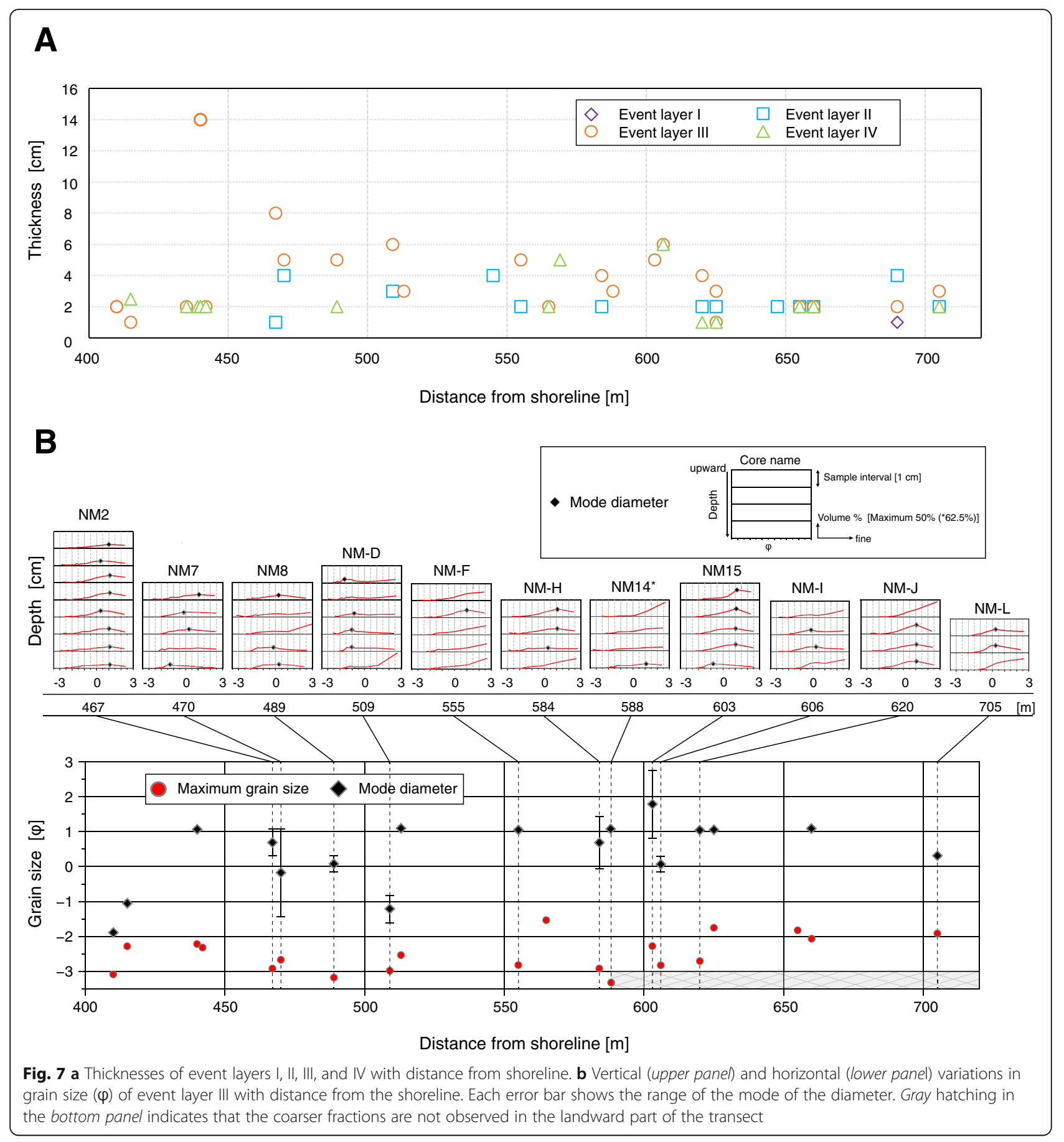

flooding is also contradictory to the landward fining and thinning of layer III. Therefore, we infer that it is highly likely that event layer III was formed by an extreme wave event.

Regarding the other event layers (I, II, and IV), event layers II and IV are consistently thin $(1-2 \mathrm{~cm})$ throughout the transect (Fig. 7). The interpretation of event layer I is uncertain because little evidence of the layer was found in the survey area. Hence, although evidence is limited for event layers I, II, and IV, we interpret that these layers were also formed by extreme wave events, considering the similarities in lithology and distribution to event layer III.

We further examined the type of wave that could have formed these event layers; i.e., tsunami or storm waves. In case $2 \mathrm{C}$ (Table 1 ), the size of the input waves was set considerably larger than the measured largest waves in Japan. The numerical simulation results for case $2 \mathrm{C}$ 
Table 2 Radiocarbon dating results

\begin{tabular}{|c|c|c|c|c|c|c|}
\hline $\begin{array}{l}\text { Sample } \\
\text { number }\end{array}$ & Core & Depth (cm) & Material & $\begin{array}{l}\text { Conventional } \\
\text { radiocarbon age (yrBP) }\end{array}$ & $\begin{array}{l}\text { Calibrated age } \\
(2 \sigma) \text { cal BP }\end{array}$ & $\delta^{13} \mathrm{C}(\%)$ \\
\hline 1 & NM2 & $30-32$ & Organic sediment & $1910 \pm 30$ & 1920-1815 & -27.2 \\
\hline 2 & NM8 & $25-27$ & Organic sediment & $2100 \pm 30$ & 2150-1995 & -27.0 \\
\hline 3 & NM-D & $35-37$ & Organic sediment & $1740 \pm 30$ & $1715-1565$ & -27.6 \\
\hline 4 & NM12 & $30-32$ & Organic sediment & $2030 \pm 30$ & 2055-1900 & -24.4 \\
\hline 5 & $\mathrm{NM}-\mathrm{F}$ & 17-19 & Organic sediment & $1910 \pm 30$ & 1920-1815 & -26.9 \\
\hline 6 & NM13 & $48-50$ & Organic sediment & $2610 \pm 30$ & $2765-2730$ & -24.1 \\
\hline 7 & $\mathrm{NM}-\mathrm{H}$ & $21-23$ & Organic sediment & $1940 \pm 30$ & 1945-1825 & -27.6 \\
\hline 8 & NM15 & $48-50$ & Organic sediment & $2170 \pm 30$ & 2305-2070 & -27.6 \\
\hline 9 & NM-I & $41-43$ & Organic sediment & $2000 \pm 30$ & 2000-1885 & -27.3 \\
\hline 10 & NM16 & $42-44$ & Organic sediment & $2070 \pm 30$ & 2120-1950 & -26.8 \\
\hline 11 & NM17 & $50-52$ & Organic sediment & $2000 \pm 30$ & 2000-1885 & -26.8 \\
\hline 12 & NM-K & $18-20$ & Organic sediment & $1300 \pm 30$ & 1290-1180 & -27.4 \\
\hline 13 & NM-K & $30-32$ & Organic sediment & $2050 \pm 30$ & 2115-1930 & -26.6 \\
\hline 14 & NM-K & $34-36$ & Organic sediment & $2100 \pm 30$ & 2150-1995 & -26.5 \\
\hline 15 & NM-K & $40-42$ & Organic sediment & $2170 \pm 30$ & 2305-2070 & -26.2 \\
\hline 16 & NM-K & $44-45$ & Organic sediment & $2190 \pm 30$ & 2310-2120 & -24.3 \\
\hline 17 & NM-K & $51-53$ & Organic sediment & $2480 \pm 30$ & 2720-2385 & -25.2 \\
\hline 18 & NM-K & $54-55$ & Organic sediment & $2570 \pm 30$ & $2750-2710$ & -26.6 \\
\hline 19 & NM18 & $25-27$ & Organic sediment & $2150 \pm 30$ & 2300-2055 & -26.9 \\
\hline 20 & NM19 & $41-43$ & Organic sediment & $2160 \pm 30$ & 2305-2065 & -24.7 \\
\hline
\end{tabular}

All data were obtained by accelerator mass spectroscopy (AMS). Sample numbers correspond to those in Figs. 4 and 5

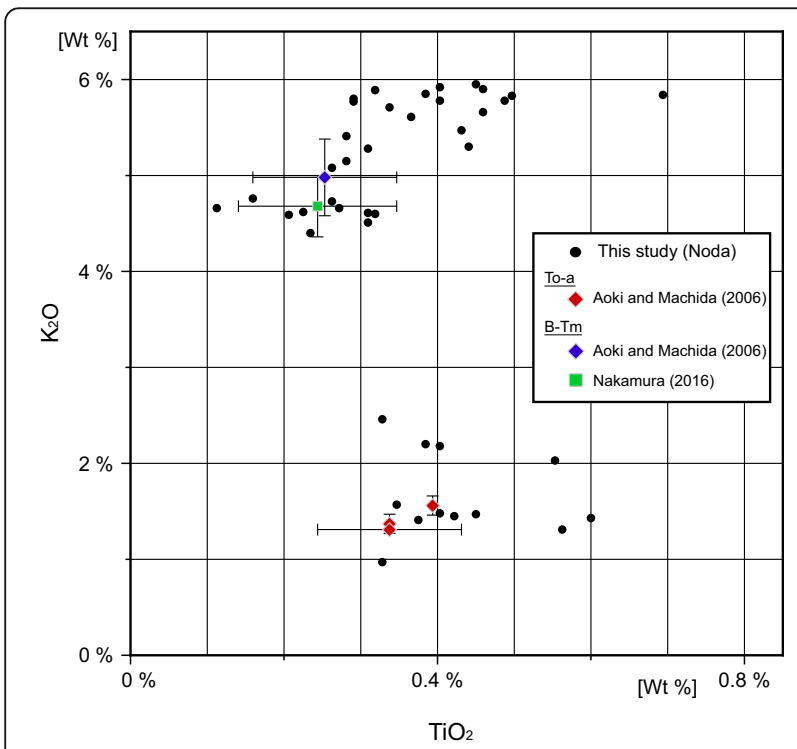

Fig. $8 \mathrm{~K}_{2} \mathrm{O}-\mathrm{TiO}_{2}$ diagram for glass shards. The red, blue, and green symbols indicate marker tephras from Aoki and Machida (2006) and Nakamura (2016). Error bars show the range of values show that storm waves reached only $450 \mathrm{~m}$ inland of the shoreline. The storm waves failed to inundate most of the transect (distance from the shoreline, 410$710 \mathrm{~m}$ ). Therefore, it is likely that such storm conditions did not affect the study area. As for the strength of storms, Mishima et al. (2009) proposed that seawater temperature is the most important factor. According to Koizumi and Sakamoto (2010), the sea surface temperatures around Japan have been almost constant for the past 3000 years. Multi-decadal climate fluctuations in the NW Pacific Ocean also affect seawater temperature. However, Mishima et al. (2009) showed that seawater temperature, which has a cycle of $30-40$ years, has had less of an influence on multi-decadal climate fluctuations, based on records from the last several hundred years. Therefore, it is likely that there has been no clear change in storm strength over the past 3000 years. Goto et al. (2013) also suggested, based on a study of coastal boulders deposited on fringing reefs by storm waves in the Ryukyu Islands, southern Japan, that storm wave impacts during at least the past 2300 years have remained stable. Therefore, it is reasonable to infer that the extremely large storm waves assumed in this study are not likely to have occurred over the past several thousand years. 

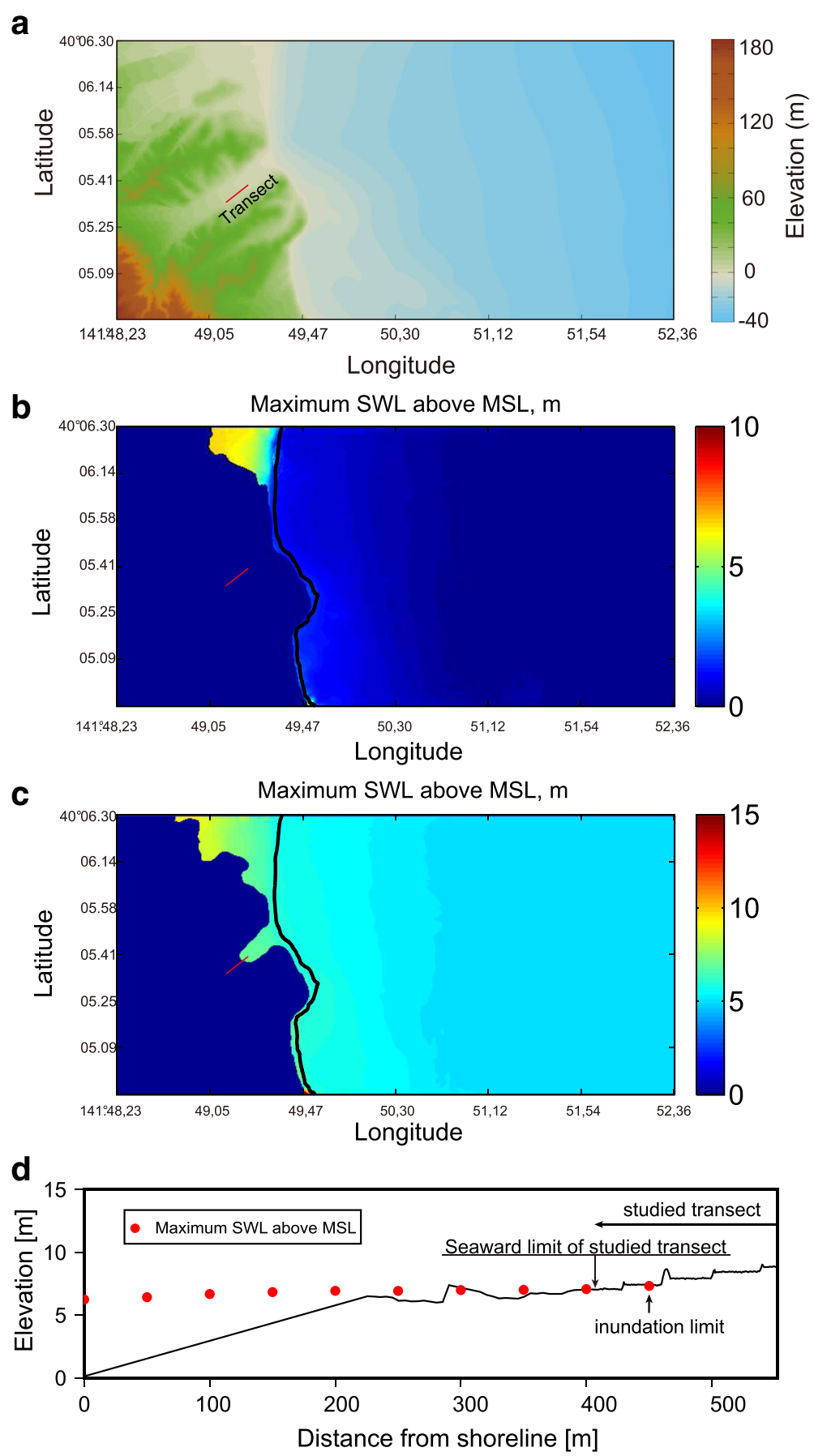

Fig. 9 a Domain of the numerical experiment. The red line denotes the transect. Numerical results are shown for maximum seawater level of b case 1C (20 m wave height, $20 \mathrm{~s}$ period, and water level $0 \mathrm{~m}$ ) and c case $2 \mathrm{C}$ (20 m wave height, $20 \mathrm{~s}$ period, and water level $5 \mathrm{~m}$ ). Black line denotes the shoreline. $\mathbf{d}$ Cross-sectional profile of the maximum seawater level (red points) above the mean sea level in case $2 \mathrm{C}$. A minor discrepancy between the red points and altitude data occurs because of the difference between our own measured altitude data along the transect and the topographic data used for the numerical simulation

The inundation distance of former large storm waves can be related to the paleo-shoreline position and paleoelevation. The shoreline position of the study area has changed as the Sanriku coast has been eroded by disproportionate littoral drift, resulting in a reduction in sediment supply from rivers, and by the settlement of artificial embankments (Tanaka 1980; Kinokuni and Udo 2015). This coastal erosion has occurred in the past 20 
100 years, so it may not be applicable directly to millennium-scale environmental change. However, our survey site is a backland located behind a pocket beach surrounded by rocky cliffs (Fig. 2a). Therefore, the shoreline might have been stable or shifted landwards in response to past erosion of the rocky cliffs. This shift suggests that the paleo-shoreline would have been located farther offshore than its present position if we consider coastal erosion. If we assume that the shoreline position was farther offshore than the present position, then the calculated inundation limits of the storm waves in this study should be shifted seaward.

Pleistocene marine terraces along the Sanriku coast, especially along the northern Sanriku coast, have been interpreted as evidence of long-term crustal uplift over several $\sim 200,000$ years (Koike and Machida 2001). The crustal uplift may change our numerical results of inundation distance by a storm wave. The marine terrace (MIS 5e, $125 \mathrm{ka}$ ) stretches continuously from Hachinohe to Kuji, which is located just north of Noda (Niwa and Sugai 2016). The uplift rate at Kuji is estimated to be $0.2 \mathrm{~mm} /$ year based on the elevation of a marine terrace (Koike and Machida 2001). On the southern Sanriku coast (south of Miyako), where there is little information on the marine terraces, Niwa et al. (2014, 2015) reported that the Rikuzentakata and Kesennuma locations have undergone subsidence during the Holocene, yielding subsidence rates of $0.6-1.3$ and $0.9-1.8 \mathrm{~mm} /$ year, respectively. Niwa and Sugai (2016) also pointed out that the Sanriku coast tilts from north (uplift) to south (subsidence). It is unclear whether Noda Village has been affected by this tilting. As Noda Village is located between Kuji and the southern Sanriku coast, it is reasonable to assume that no great crustal uplift has occurred near the study area during the past 2700 years, although a future study of crustal movement in this area is required.

Based on this evidence, it is unlikely that the event layers were formed by storm waves. The 2011 Tohokuoki and 1896 Meiji Sanriku tsunamis inundated far beyond the possible maximum limit of storm waves and fully covered the distribution area of the event layers (Fig. 3b). Therefore, while the event layers do not show the laminations or shell fragments that are apparent in the 2011 tsunami deposits, we infer that the event layers were probably formed by tsunami waves.

\section{Paleo-tsunami history and size}

In core NM-K, the To-a (AD 915) and B-Tm (AD 946) tephras lie immediately above layer I. The absence of tsunami deposits above the tephra layers might be the result of recent agricultural disturbance. In fact, historical documents describe damage resulting from the AD 1611 Keicho tsunami near the study area (Imamura
1934; Tsuji and Ueda 1995). Hirakawa (2012), Ishizawa et al. (2015), and Takada et al. (2016) described a possible AD 1611 tsunami deposit near the present study site. Moreover, the AD 1896 tsunami certainly inundated beyond the inland limit of the 2011 tsunami, but no geological evidence remains because of anthropogenic disturbance. Therefore, we discuss the tsunami history for the period before deposition of the To-a and B-Tm tephras in the tenth century.

The radiocarbon dating and tephra results show that the ages of layers I-IV in core NM-K are 1290-1004, 2150-1930, 2310-2070, and 2750-2385 cal BP, respectively, (Fig. 6). The age of layer I can probably be correlated with the AD 869 Jogan tsunami event. No historical documentation has been found from this area that describes the AD 869 Jogan earthquake and tsunami. In recent studies, possible AD 869 Jogan tsunami deposits at Koyadori have been regarded as the northern limit of its distribution (Ishimura and Miyauchi 2015; Fig. 1). The identification of possible AD 869 Jogan tsunami deposits at the Noda Village site suggests that the tsunami affected areas farther north of the Sanriku region. If this is the case, then our study site currently defines one of the northern extents of the AD 869 Jogan tsunami. This is an important step towards improving the tsunami source model in future work. However, it should be mentioned that Takada et al. (2016) suggested another possible AD 869 Jogan tsunami deposit at Harashinai, $\sim 25 \mathrm{~km}$ north of Noda, but the age of the deposit is not well constrained by tephra chronology.

Our results are also useful for refining our estimation of the tsunami recurrence interval along the Sanriku coast. At the study site, it is likely that four large tsunamis inundated the area between approximately 1100 and 2700 cal BP. It is noteworthy that four tsunami deposits are identified within the cores at approximately even intervals, although it might be necessary to consider the influence of sedimentation rates and erosion. The recurrence interval is estimated at 400-600 years.

Ishimura (2017) reported that five tsunamis (E4 (the 869 Jogan tsunami) to E8) occurred during the 1779 years between 1081 and $2860 \mathrm{cal} \mathrm{BP}$ at Koyadori (Fig. 1), compared with the four events at the present study site. Although the correlation of tsunami deposits between the two sites is not easy because of the wide age range, it is likely that the same tsunamis affected both sites. One possible reason for the one-fewer event bed at our study site is that it is located at a higher elevation than Koyadori. Therefore, it is possible that smaller tsunamis did not leave deposits in the study area. The location of the paleotsunami source and the difference in the direction of bay entrances at Noda and Koyadori may have also influenced the number of event layers. 
It is noteworthy that all four tsunami deposits of the present study occur close to the inundation limit of the 2011 Tohoku-oki tsunami. The 2011 tsunami inundation was affected by artificial embankments. For that reason, it is difficult to compare the extent of inundation of the 2011 tsunami and older tsunamis directly. However, it is reasonable to speculate that the local sizes of paleo-tsunamis were equivalent to those of the 2011 Tohoku-oki or 1896 Meiji Sanriku tsunamis when we consider the landward extent of each tsunami deposit. Future numerical modeling is needed to elucidate the sources of the pre-historical tsunami events.

\section{Conclusions}

We identified four tsunami deposits in Noda Village, Iwate Prefecture, along the northern Sanriku coast, based on the distribution and sedimentary features of deposits and numerical modeling results. The results show that even unusually large storm waves with high sea-level rise caused by low atmospheric pressure fail to explain the distribution of event deposits. Numerical methods can be a useful tool in identifying tsunami deposits if the maximum possible storm waves are assumed. The ages of the tsunami deposits suggest that four large tsunamis occurred in this area during the 1600 years between 1100 and $2700 \mathrm{cal}$ BP, the youngest of which might have been the AD 869 Jogan event. Considering the landward extents of the respective tsunami deposits, the local inundation extent of the tsunamis might have been similar to that of the 2011 or 1896 tsunamis, although the tsunami sources are uncertain.

\section{Additional file}

Additional file 1: Table A1. Characteristics of gravelly sand deposits. (PDF $368 \mathrm{~kb})$

\section{Abbreviations}

B-Tm: Baedusan-Tomakomai; MIS: Marine isotope stage; To-a: Towada-a

\section{Acknowledgements}

This research was supported by the JSPS research funds (no. 26242033) and funds from IRIDeS, Tohoku University. CT image analysis was conducted at the Center for Advanced Marine Core Research in Kochi University (accept no. 14B041). We especially thank a landowner for giving us permission to conduct surveys and for providing useful information. We thank T. Ishizawa for his assistance during the field survey and M. Yamada and S. Fujino for their assistance during grain size measurements. We thank J. D. Bricker for help with the numerical simulation and K. Edwards for helpful comments on editing the English version of the manuscript. J. Matsumoto, K. Ikehara, W. Szczuciński, and an anonymous reviewer provided valuable comments that improved the manuscript. We thank all of these people for their support.

\section{Funding}

Not applicable

\section{Authors' contributions}

All authors conducted field surveys, collected samples, and participated in discussions during the research. Additionally, TI mainly performed the experiments and wrote the paper. KG proposed the study topic, and conceived and designed the study. YN conducted the survey related to the 2011 tsunami deposits and tephra analysis. MW and TI performed the numerical simulation related to storm waves using Delft 3D. All authors read and approved the final manuscript.

\section{Competing interests}

The authors declare that they have no competing interests.

\section{Publisher's Note}

Springer Nature remains neutral with regard to jurisdictional claims in published maps and institutional affiliations.

\section{Author details}

${ }^{1}$ Department of Earth Sciences, Graduate School of Science, Tohoku University, Sendai 980-8578, Japan. ${ }^{2}$ International Research Institute of Disaster Science, Tohoku University, 468-1 Aza-Aoba, Aramaki, Aoba-ku, Sendai 980-0845, Japan. ${ }^{3}$ Institute of Seismology and Volcanology, Faculty of Science, Hokkaido University, Sapporo, Hokkaido 060-0810, Japan.

${ }^{4}$ Department of Civil and Environmental Engineering, Graduate School of Engineering, Tohoku University, 468-1-305 Aza-Aoba, Aramaki, Aoba-Ku, Sendai 980-0845, Japan. ${ }^{5}$ Department of Earth Sciences, Graduate School of Science, Tohoku University, Sendai 980-8578, Japan. Present address: INPEX Corporation, Akasaka Biz Tower 5-3-1, Akasaka, Minato-ku, Tokyo 107-6332, Japan. ${ }^{6}$ Department of Earth Sciences, Graduate School of Science, Tohoku University, Sendai 980-8578, Japan. Present address: Museum of Natural and Environmental History, 5762 Oya, Suruga-ku, Shizuoka, Shizuoka Prefecture 422-8017, Japan.

Received: 7 January 2017 Accepted: 11 December 2017

Published online: 28 December 2017

\section{References}

Abe H, Sugeno Y, Chigama A (1990) Estimation of the height of the Sanriku Jogan 11 earthquake-tsunami (AD 869) in the Sendai Plain. Zisin J Seis Soc Japan Second Ser 43(4):513-525 (in Japanese, with English abstract)

Aoki K, Machida H (2006) Major element composition of volcanic glass shards in the late Quaternary widespread tephras in Japan--distinction of tephras using $\mathrm{K}_{2} \mathrm{O}-\mathrm{TiO}_{2}$ diagrams. Bull Geol Surv Japan 57:239-258

Booij N, Ris RC, Holthuijsen LH (1999) A third-generation wave model for coastal regions: 1. Model description and validation. J Geophys Res Oceans 104(C4):7649-7666

Bricker JD, Takagi H, Mas E, Kure S, Adriano B, Yi C, Roeber V (2014) Spatial variation of damage due to storm surge and waves during typhoon Haiyan in the Philippines. J Japan Soc Civ Eng Ser B2 (Coastal Engineering) 70(2):I_231-I_235

Dawson AG (1994) Geomorphological effects of tsunami run-up and backwash. Geomorphology 10(1):83-94

Dawson AG, Shi S (2000) Tsunami deposits. Pure Appl Geophys 157(6-8):875-897

Deltares (2011) Delft3D-FLOW user manual. Version 3.15

Goff J, Chagué-Goff C, Nichol S, Jaffe B, Dominey-Howes D (2012) Progress in palaeotsunami research. Sedi Geol 243:70-88

Goto K, Chagué-Goff C, Fujino S, Goff J, Jaffe B, Nishimura Y, Richmond B, Suguwara D, Szczucinski W, Tappin DR, Witter R, Yulianto E (2011) New insights of tsunami hazard from the 2011 Tohoku-oki event. Mar Geol 290:46-50

Goto K, Fujino S, Sugawara D, Nishimura Y (2014) The current situation of tsunami geology under new policies for disaster countermeasures in Japan. Episodes 37:258-264

Goto K, Miyagi K, Imamura F (2013) Localized tsunamigenic earthquakes inferred from preferential distribution of coastal boulders on Ryukyu Islands, Japan. Geology 41:1139-1142

Goto T, Satake K, Sugai T, Ishibe T, Harada T, Murotani S (2015) Historical tsunami and storm deposits during the last five centuries on the Sanriku coast, Japan. Mar Geol 367:105-117

Hatori T (2009) Regional deviation of inundation heights due to the large Sanriku tsunamis. Histo Earthq 24:41-48

Henphill-Haley E (1996) Diatoms as an aid in identifying late-Holocene tsunami deposits. The Holocene 6(4):439-448

Hirakawa K (2012) Large tsunami history along the Chishima and Japan trenches. Iwanami-Kagaku 82:172-181 (in Japanese) 
Imamura A (1934) Past tsunamis of the Sanriku District. Bull Earthq Res Inst Tokyo Univ 1:1-16 (in Japanese, with English abstract)

Ishimura D (2017) Re-examination of the age of historical and paleo-tsunami deposits at Koyadori on the Sanriku Coast, Northeast Japan. Geosci Lett 4(1):11

Ishimura D, Miyauchi T (2015) Historical and paleo-tsunami deposits during the last 4000 years and their correlations with historical tsunami events in Koyadori on the Sanriku Coast, northeastern Japan. Prog Earth Planet Sci 2(1):16

Ishizawa T, Goto K, Yokoyama Y, Miyairi Y, Sawada C, Nishimura Y, Sugawara D (2015) High-precision ${ }^{14} \mathrm{C}$ dating of tsunami deposits at northern Sanriku, Japan. In: Abstracts of the Arthur Holmes meeting. The Geological Society, London 25 September 2015

Japan tsunami trace database. 2018. http://tsunami-db.irides.tohoku.ac.jp. Accessed 28 Sept 2016.

Kanamori H (1971) Seismological evidence for a lithospheric normal faulting-the Sanriku earthquake of 1933. Phys Earth Planet Interiors 4(4):289-300

Kawaguchi K, Inomata T, Seki K, Fujiki T (2015) Annual report on nationwide ocean wave information network for ports and harbors (NOWPHAS 2013). Tec note Port Airport Res Inst 1305:2-119. http://www.pari.go.jp/unit/kaisy/ nowphas/annuareport/nowp2013.html. Accessed 25 Nov 2016

Kinokuni R, Udo K (2015) Characteristics of long term shoreline change in Japan. J Japan Soc Civ Eng Ser B2 (Coastal Engineering) 71(2):I_613-I_618

Koike K, Machida H (2001) Atlas of quaternary marine terraces in the Japanese islands. University of Tokyo Press, Tokyo

Koizumi I, Sakamoto T (2010) Synchronous Td'-derived SSTs $\left({ }^{\circ} \mathrm{C}\right)$ off Japan with climatic in the northern hemisphere. Jour Tokyo Geogra Soc 119(3):489-509

Machida H, Arai F (1992) Atlas of Tephra in and around Japan. University of Tokyo press, Tokyo

Machida H, Arai F (2003) Atlas of Tephra in and around Japan [revised edition]. University of Tokyo Press, Tokyo

Matsumoto H, Yoshida M, Kumagai M (2012) Paleo-tsunami and the 2011 Tsunami Deposits on the Sendai Coastal Lowland, Northeast Japan. J Geomor 33(4):385-389

Minoura K, Hirano S, Yamada T (2013) Identification and possible recurrence of an oversized tsunami on the Pacific coast of northern Japan. Nat Haz 68(2):631-643

Minoura K, Imamura F, Sugawara D, Kono Y, Iwashita T (2001) The 869 Jogan tsunami deposit and recurrence interval of large-scale tsunami on the Pacific coast of northeastern Japan. J Nat Dis Sci 23(2):83-88

Minoura K, Nakaya S (1991) Traces of tsunami preserved in inter-tidal lacustrine and marsh deposits: some examples from northeastern Japan. J Geol 99(2):265-287

Minoura K, Nakaya S, Uchida M (1994) Tsunami deposits in a lacustrine sequence of the Sanriku coast, northeastern Japan. Sedi Geol 89(1-2):25-31

Mishima T, Yamashita T, Matsuoka K, Komaguchi T (2009) Study on the multidecadal fluctuation of climate change and typhoon. J Japan Soc Civ Eng Ser B2 (Coastal Engineering) 56:1276-1280

Morton RA, Gelfenbaum G, Jaffe BE (2007) Physical criteria for distinguishing sandy tsunami and storm deposits using modern examples. Sedi Geol 200(3):184-207

Nakamura Y (2016) Stratigraphy, distribution, and petrographic properties of Holocene tephras in Hokkaido, northern Japan. Quat Int 397:52-62

Namegaya Y, Satake K (2014) Reexamination of the AD 869 Jogan earthquake size from tsunami deposit distribution, simulated flow depth, and velocity. Geophys Res Lett 41:2297-2303

Namegaya Y, Satake K, Yamaki S (2010) Numerical simulation of the AD 869 Jogan tsunami in Ishinomaki and Sendai plains and Ukedo river-mouth lowland. Annual Report of Active Fault and Paleoearthquake Researches 10: 1-21 (in Japanese, with English abstract)

Nishina K, Kawakami G, Tajika J (2013) Gravel deposits formed by the 2011 Tohoku earthquake tsunami along the Sanriku coast. Rep Geol Sur Hokkaido 85:27-44

Niwa Y, Sugai T (2016) Geomorphology and tectonic setting of the Sanriku coast, northeastern Japan, and introduction of recent studies on the formation of alluvia plains and Holocene crustal movements along the coast. In: Haruyama S, Sugai T (eds) Natural disaster and coastal geomorphology. Springer, Cham, pp 15-36

Niwa Y, Sugai T, Matsushima Y (2015) Holocene crustal movement in the Kesennuma Okawa Plain, southern Sanriku Coast, northeastern Japan, estimated from coastal geology. J Geogr 124:545-560

Niwa Y, Toda S, Sugai T, Matsushima Y (2014) Holocene sedimentary facies, sediment accumulation rate and coastal subsidence estimated from a sediment core in the Rikuzentakata Plain, northeast Japan. Quat Res (Daiyonki-Kenkyu) 53:311-322
Ozawa S, Nishimura T, Suito H, Kobayashi T, Tobita M, Imakiire T (2011) Coseismic and postseismic slip of the 2011 magnitude-9 Tohoku-Oki earthquake. Nature 475(7356):373-376

Peterson CD, Carver GA, Cruikshank KM, Abramson HF, Garrison Laney CE, Dengler LA (2011) Evaluation of the use of paleotsunami deposits to reconstruct inundation distance and runup heights associated with prehistoric inundation events, Crescent City, southern Cascadia margin. Earth Surf Proc Land 36(7):967-980

Pinegina TK, Bourgeois J (2001) Historical and paleo-tsunami deposits on Kamchatka, Russia: long-term chronologies and long-distance correlations. Nat Haz Earth Sys Science 1(4):177-185

Reimer PJ, Bard E, Bayliss A, Beck JW, Blackwell PG, Bronk RC, Buck CE, Cheng H, Edwards RL, Friedrich M, Grootes PM, Guilderson TP, Haflidason H, Hajadas I, Hatte C, Heaton TJ, Hoffmann DL, Hogg AG, Reimer RW, Richards DA, Scott EM, Southon JR, Staff RA, Turney CSM, van der Plicht J (2013) IntCal13 and Marine13 radiocarbon age calibration curves 0-50,000 years cal BP. Radiocarbon 55(4):1869-1887

Satake K, Namegaya Y, Yamaki S (2008) Numerical simulation of the AD 869 Jogan tsunami in Ishinomaki and Sendai plains. Annual Report of Active Fault and Paleoearthquake Researches 8:71-89 (in Japanese, with English abstract)

Sawai Y, Namegaya Y, Okamura Y, Satake K (2012) Challenges of anticipating the 2011 Tohoku earthquake and tsunami using coastal geology. Geophys Res Lett 39:L21309

Sawai Y, Namegaya Y, Tamura T, Nakashima R, Tanigawa K (2015) Shorter intervals between great earthquakes near Sendai: scour ponds and a sand layer attributable to AD 1454 overwash. Geophys Res Lett 42(12):4795-4800

Sawai Y, Shishikura M, Komatsubara J (2008) Study of paleotsunami using hand corer in Sendai plain (Sendai City, Natori City, Iwanuma City, Watari Town, Yamamoto Town), Miyagi, Japan. Annual Report on Active Fault and Paleoearthquake Researches 8:17-70 (in Japanese, with English abstract)

Sawai Y, Shishikura M, Okamura Y, Takada K, Matsuura T, Aung TT, Komatsubara J, Fujii Y, Fujiwara O, Satake K, Kamataki T, Sato N (2007) A study of paleotsunami using handy geoslicer in Sendai Plain (Sendai, Natori, Iwanuma, Watari, and Yamamoto), Miyagi, Japan. Annual Report on Active Fault and Paleoearthquake Research 7:47-80 (in Japanese, with English abstract)

Shishikura M, Sawai Y, Okamura Y, Komatsubara J, Aung TT, Ishiyama T, Fujiwara O, Fujino S (2007) Age and distribution of tsunami deposit in the Ishinomaki Plain, Northeastern Japan. Annual Report on Active Fault and Paleoearthquake Researches 7:31-46 (in Japanese, with English abstract)

Sugawara D, Goto K, Imamura F, Matsumoto H, Minoura K (2012) Assessing the magnitude of the 869 Jogan tsunami using sedimentary deposits: prediction and consequence of the 2011 Tohoku-oki tsunami. Sedi Geol 282:14-26

Sugawara D, Imamura F, Goto K, Matsumoto H, Minoura K (2013) The 2011 Tohoku-oki earthquake tsunami: similarities and differences to the 869 Jogan tsunami on the Sendai plain. Pure Appl Geophys 170(5):831-843

Sugawara D, Minoura K, Imamura F (2001) Sedimentation and numerical reconstruction of AD869 Jogan tsunami. DCRC Tsunami Eng Tech Rep 18:1-10 (in Japanese)

Takada K, Nakata T, Miyagi T, Haraguchi T, Nishitani Y (2002) Handy Geoslicer-new soil sampler for Quaternary geologist. Chisitsu News 579:12-18 (in Japanese with English abstract)

Takada K, Shishikura M, Imai K, Ebina Y, Goto K, Koshiya S, Yamamoto H, Igarashi A, Ichihara T, Kinoshita H, Ikeda T, River Division Department of prefectural Land Development, Iwate Prefecture Government (2016) Distribution and ages of tsunami deposits along the Pacific Coast of the Iwate Prefecture. Annual Report on Active Fault and Paleoearthquake Research 16:1-52 (in Japanese with English abstract)

Tanaka N (1980) Regional division of seaside in Japan from a coastal engineering perspective. Japan Soc Civ Eng 27:211-215 (in Japanese)

Tanigawa K, Sawai Y, Shishikura M, Namegaya Y, Matsumoto D (2014) Geological evidence for an unusually large tsunami on the pacific coast of Aomori, northern Japan. J Quat Sci 29(2):200-208

Tanioka Y, Satake K (1996) Tsunami generation by horizontal displacement of ocean bottom. Geophys Res Lett 23(8):861-864

Tanioka Y, Seno T (2001) Sediment effect on tsunami generation of the 1896 Sanriku tsunami earthquake. Geophys Res Lett 28(17):3389-3392

Terui K, Nagahama H (1995) Depositional facies and sequences of the Upper Cretaceous Kuji Group, northeastern Japan. Mem Geol Soc Japan 45:238-249

The 2011 Tohoku Earthquake Tsunami Joint Survey (TTJS) Group. http://www. coastal.jp/ttjt/. Accessed 10 May 2016 
Tsuji Y, Ueda K (1995) Evaluation of AD 1611 Keicho, AD 1677 Enpou, AD 1763 Houreki, AD 1793 Kansei, and AD 1856 Ansei Sanriku tsunamis. Histo Earthq 11:75-106

Utsu T (2004) Catalog of damaging earthquakes in the world (through 2002), Tokyo. http://iisee.kenken.go.jp/utsu/index_eng.html. Accessed 1 Feb 2016 Vogel JC, Fulf A, Visser E, Becker B (1993) A simplified approach to calibrating ${ }^{14} \mathrm{C}$ dates. Radiocarbon 33:73-86

Watanabe M, Bricker JD, Goto K, Imamura F (2017) Factors responsible for the limited inland extent of sand deposits on Leyte Island during 2013 typhoon Haiyan. J Geophys Res Oceans 122:2795-2812

Yamada M, Fujino S (2013) Sedimentary characteristics of the onshore tsunami deposits formed by the 2011 Tohoku-oki tsunami in coastal lowlands, Ibaraki and Chiba prefectures. J Sedi Soc Japan 72:13-25

\section{Submit your manuscript to a SpringerOpen ${ }^{\bullet}$} journal and benefit from:

- Convenient online submission

- Rigorous peer review

- Open access: articles freely available online

- High visibility within the field

- Retaining the copyright to your article

Submit your next manuscript at $>$ springeropen.com 